\title{
Quantity, Quality and Cost of Household Waste in Al-Diwaniyah Governorate
}

\author{
Ammar Subhy Shaker and Faez Saleh Mohammed ${ }^{\text {a) }}$ and Hawraa G.T.Al-Shebani \\ Faculty of Agriculture, University of Al-Qadisiah, Iraq. \\ a) Corresponding Author: faezsalih18@gmail.com
}

\author{
Received : 2/3/2021 \\ Acceptance : 5/4/2021 \\ Available online: $31 / 12 / 2021$
}

\begin{abstract}
In the current stage is to calculate the daily generated quantities of solid household waste, as well as to indicate the annual amounts spent on the stages of collection, transportation and landfilling of this waste, as well as to identify the practical reality of the processes and stages of solid household waste management followed by the municipal institutions of the governorate to indicate the possibility of establishing an investment project Dedicated to recycling plastic, paper and glass materials and benefiting from organic materials as fertilizers for the soil or for energy production, with the aim of activating sustainable development in the governorate.
\end{abstract}

Keywords. Quantity, Al-Diwaniyah, Quality.

\section{INTRODUCTION}

Waste is generally defined as all residues resulting from production, transformation or use processes, or that need to be disposed of or removed in order not to harm human health and the environment. Waste includes many types and multiple classifications. There are solid waste, liquid waste, industrial waste, medical waste and hazardous waste. and others.

The sources of solid waste are the resulting from domestic, commercial, industrial and agricultural uses, construction waste, construction and demolition. Solid waste is also classified according to its nature into organic and inorganic waste, rottenable and non-rottenable waste, and combustible and non-combustible waste.

In this study, we focused on solid household waste, which is the most prominent source of environmental pollution, as its harmful effects sweep all components of the environmental envelope from soil, surface water and air, and their negative impact extends to the underground water and change in soil properties.

Household solid waste means the waste resulting from homes and restaurants, waste (kitchens, hotels, streets) and commercial waste, in addition to garbage or other violations of social life. Hydrogen), which is composed mainly of foodstuffs such as vegetables, fruits, meat and bread - and inorganic waste such as glass, plastic, metal, nylon, and others.

The development of an integrated waste management system has become one of the most important strategies of countries to find a special orientation towards waste collection and disposal and to innovate administrative, technical, technical and economic methods that ensure the various operations of collection, disposal, treatment and recycling and the use of modern methods and techniques and modern trends in these areas to achieve the requirements of sustainable development on the one hand and from Another aspect is the protection of humans, animals and plants from pollutants and the beautification of the governorate. Household waste is a national wealth from which we can produce important economic returns if it is properly managed and treated after it constitutes an economic and environmental burden, as industries can be established based on this waste.

\section{RESULTS AND DISCUSSION}

1. There is no sorting of household waste and that the operations carried out by municipal institutions in the governorate are limited only to the processes of collection and transportation to get rid of this waste. Therefore, we suggest encouraging citizens to sort waste from the source by providing them with environmentally friendly plastic bags that are biodegradable in three colors depending on the type of waste As is the case worldwide.

2. The failure to benefit from waste (as an important natural resource with economic value) makes it a burden on the citizen and the state and has a bad environmental impact. Therefore, spreading and raising environmental awareness for all segments of society plays an important role about the danger of solid waste on the one hand and its economic value on the other hand. 
3. The lack of an integrated database on this issue with the municipal institutions in the governorate. Therefore, we suggest adopting updated and accurate data for the quantity and type of waste presented, similar to this study, because it includes clear indicators for each administrative formation within the governorate, and thus provide investors with this data for the purpose of establishing a laboratory for collecting, sorting and recycling waste or converting it into useful raw materials.

4. The sanitary landfill sites in Al-Diwaniyah Governorate are irregular and do not conform to environmental determinants and are characterized by randomness. Therefore, light should be shed on these sites and their harmful environmental and health impact on the entire community of Al-Diwaniyah Governorate through studies procedures related to this subject and thus shed light on them by government agencies and increase Monitoring and follow-up in order to be subject to the environmental determinants of the landfill sites.

5. There are many legal obstacles facing investors in the field of recycling and marketing of products recycled from waste. Therefore, we suggest enacting laws regulating waste management law, especially to facilitate and encourage investment.

\section{- Diwaniyah Governorate site}

It is one of the governorates of the central Euphrates region, which is included in the sedimentary flood plain of Iraq. The astronomical location of the governorate is determined between latitudes 31.17 and 32.24 north, and longitudes 44.24 and 45.49 east. As for its administrative borders, it is bordered on the north by the governorates of Babil and Wasit, on the east by the governorates of Dhi Qar and Wasit, on the south by the Muthanna governorate, and on the west by the Najaf governorate.

\section{- Diwaniyah Governorate}

Iraq has witnessed a great development in the issue of urbanization, as the proportion of the urban population has doubled, cities have expanded and the number of their population has increased, which has generated great pressure on services of various kinds, including municipal services. 1280623 people (urban and rural) according to the statistics of the Ministry of Planning / Central Statistical Organization / Qadisiyah Statistics Directorate for the year 2016. While in 1997 about 751331 (urban and rural) people, according to the population census of the Ministry of Planning. This indicates the population increase taking place throughout the province

\section{- Administrative Divisions}

The governorate currently includes fifteen administrative units, including four districts and eleven administrative units at the level of a sub-district, as follows:

1-Al-Diwaniyah District: It includes the center of Al-Diwaniyah District, and the areas: Al-Sunniyeh, Al-Shafi'i, and AlDaghara.

2-Al-Shamiya District: It includes the center of Al-Shamiya district, and the districts of: Ghammas, Al-Mihnawiya, and Al-Salahiyah.

3-Efak District: It includes the center of Efak district, and the districts of Al Budair, Sumer, and Nefer district.

4-Al-Hamza District: It includes the center of Al-Hamza District, and my sub-districts: Al-Sudair and Al-Shanafiya

\section{- Quantities of Waste Disposed for The Whole of Al-Diwaniyah Governorate}

The quantities of solid household waste presented to the whole of Al-Diwaniyah Governorate and all its administrative divisions amounted to 257929 tons for the year 2016 based on the field surveys available to the concerned municipal sectors in the governorate for the year.

TABLE 1. Shows the quantities of solid household waste generated for the year 2016 for all administrative units of Al-Diwaniyah Governorate.

\begin{tabular}{ccc}
\hline Region & Elimination Administrative unit & Amount of solid waste (tons) per year \\
\hline \multirow{4}{*}{ Diwaniyah } & Diwaniyah District Center & 158400 \\
& Saniah & 4980 \\
& Shafi'a & 2630 \\
& Daghara & 6802 \\
Efak & Total & 172812 \\
& Efak District Center & 15240 \\
& Nuffar & 1985 \\
& Badir & 5847 \\
\hline
\end{tabular}




\begin{tabular}{ccc}
\hline & Elimination Administrative unit & Amount of solid waste (tons) per year \\
\cline { 2 - 3 } & Total & 25552 \\
Shamiya & Shamiya District Center & 12800 \\
& Ghammas & 7330 \\
& Mihnawiya & 3655 \\
& Salahia & 1746 \\
Al-Hamza & Total & 25531 \\
& Hamza District Center & 23815 \\
& Al-Sadir & 2731 \\
& Shenafia & 7288 \\
& Total & 33834 \\
& Grand total & 257729
\end{tabular}

\section{- Waste Production Rate Per Capita}

The percentage of municipal solid waste generation varies from one region to another, in terms of quantity and quality, according to the characteristics and conditions of the community, the different consumption and behavioral patterns in it, and the varying levels of income. Organic matter in the generated waste. In areas with high incomes, solid waste generation rises to more than $1 \mathrm{~kg} /$ person / day, and the percentage of organic waste decreases at the expense of recyclable materials such as paper, plastic, glass, metals, and others. The following table shows some production rates for Arab countries.

- The Country's Per Capita Production of Solid Waste Per Day $(\mathrm{kg})$

$\begin{array}{cc}\text { Jordan } & 0.9 \\ \text { UAE State } & 2.1 \\ \text { Saudi Arabia } & 1.28 \\ \text { Sudan } & 0.48 \\ \text { Tunis } & 0.64 \\ \text { Syria } & 0.49 \\ \text { Egypt } & 1.2\end{array}$

It is noted that the highest rates of the amount of waste produced are found in the United States of America and the Arab Gulf states, as is clear from the following table:

Lowest income regions in Southeast Asia and Africa $4.0 \mathrm{~kg} /$ person / day Typical cities in Asia, North Africa and South America $7.0 \mathrm{~kg} /$ person / day Typical cities in industrialized countries $\quad 1,1 \mathrm{~kg} / \mathrm{person} / \mathrm{day}$

Some cities in rich regions (USA and Gulf countries) $\quad 9,1 \mathrm{~kg} /$ person / day Source: Arab Educational, Cultural and Scientific Organization

Urban Engineering and Environmental Sciences - Volume Two - Tunis 2003

In Al-Diwaniyah Governorate (the subject of the study), the per capita production rate was 0.967, as shown in the table below

TABLE 2. Shows the population and the daily production rate per capita for all the administrative units of Al-Diwaniyah Governorate.

\begin{tabular}{|c|c|c|c|c|}
\hline \multirow[b]{2}{*}{ Region } & \multirow[b]{2}{*}{ Administrative unit } & \multirow[b]{2}{*}{$\begin{array}{l}\text { Population } \\
\text { (urban) }\end{array}$} & \multicolumn{2}{|l|}{$\begin{array}{r}\text { Amount of household solid waste } \\
\end{array}$} \\
\hline & & & $\begin{array}{c}\text { the amount of solid household waste disposed } \\
\text { per administrative unit ton / day }\end{array}$ & per person kg / day \\
\hline \multirow{5}{*}{ Diwaniyah } & Diwaniyah District Center & 403726 & 440 & 1.089 \\
\hline & Saniah & 10939 & 13.38 & 1.22 \\
\hline & Shafi'a & 11606 & 7.30 & 0.62 \\
\hline & Daghara & 20526 & 18.9 & 0.92 \\
\hline & Total & 446798 & 479.58 & \\
\hline \multirow{5}{*}{ Efak } & Efak District Center & 35529 & 42.33 & 1.19 \\
\hline & Nuffar & 4216 & 5.51 & 1.3 \\
\hline & Badir & 19851 & 16.24 & 0.81 \\
\hline & Sumer & 11259 & 6.88 & 0.61 \\
\hline & Total & 70854 & 70.96 & \\
\hline \multirow{2}{*}{ Shamiya } & Shamiya District Center & 57997 & 35.5 & 0.61 \\
\hline & Ghammas & 34683 & 20.36 & 0.58 \\
\hline
\end{tabular}




\begin{tabular}{ccccc}
\hline & Mihnawiya & 10157 & 10.15 & 0.99 \\
& Salahia & 3665 & 4.85 & 1.32 \\
Al-Hamza & Total & 106503 & 70.87 & 0.76 \\
& Hamza District Center & 86727 & 66.15 & 0.99 \\
& Al-Sadir & 7628 & 7.58 & 0.96 \\
& Shenafia & 20963 & 20.24 & 0.967 \\
\hline
\end{tabular}

\section{- Machines Used to Lift and Transport Waste}

The municipality uses various types and forms of mechanisms for raising, collecting and transporting solid household waste from different residential areas to sanitary landfill sites. The following is a table of the number of mechanisms used to transport waste to sanitary landfill sites for the entire Diwaniyah Governorate.

TABLE 3. Shows the number of mechanisms used to transport waste to sanitary landfill sites for the whole of Al-Diwaniyah Governorate.

\begin{tabular}{|c|c|c|}
\hline Region & & $\begin{array}{l}\text { Administrative unit Number of mechanisms used to transport waste to sanitary landfill } \\
\text { sites Load (4 tons) }\end{array}$ \\
\hline \multirow{6}{*}{ Diwaniyah } & Diwaniyah District & e \\
\hline & Center & \\
\hline & Saniah & 2 \\
\hline & Shafi'a & 4 \\
\hline & Daghara & 6 \\
\hline & Total & 90 \\
\hline \multirow{5}{*}{ Efak } & Efak District Center & 5 \\
\hline & Nuffar & 3 \\
\hline & Badir & 5 \\
\hline & Sumer & 3 \\
\hline & Total & 16 \\
\hline \multirow{4}{*}{ Shamiya } & $\begin{array}{l}\text { Shamiya District } \\
\text { Center }\end{array}$ & 5 \\
\hline & Ghammas & 8 \\
\hline & Mihnawiya & 5 \\
\hline & Salahia & 4 \\
\hline \multirow{6}{*}{ Al-Hamza } & Total & 22 \\
\hline & Hamza District Center & 9 \\
\hline & Al-Sadir & 3 \\
\hline & Shenafia & 4 \\
\hline & Total & 16 \\
\hline & Grand total & 144 \\
\hline
\end{tabular}

\section{- The Money Spent on Raising and Transporting Waste}

The amounts spent annually to raise, transport and land this waste amount to (329,2257,000 dinars) for the year 2016. As shown in the table below and according to the data supplied by the Directorate of Diwaniyah Municipality and the Directorate of Diwaniyah Municipalities for the year 2016, which included in its paragraphs: workers' wages, the amounts spent on machinery fuel for the year 2016

TABLE 4. Shows the total amounts disbursed for the year 2016 (workers' wages + fuel) on solid household waste.

\begin{tabular}{|c|c|c|c|}
\hline Judiciary & Administrative unit & Amounts disbursed dinars / year & Notes \\
\hline \multirow{4}{*}{ Diwaniyah } & Diwaniyah District Center & 555000000 & \\
\hline & Saniah & 92084000 & \\
\hline & Shafi'a & 102768000 & \\
\hline & Daghara & 173404000 & \\
\hline
\end{tabular}




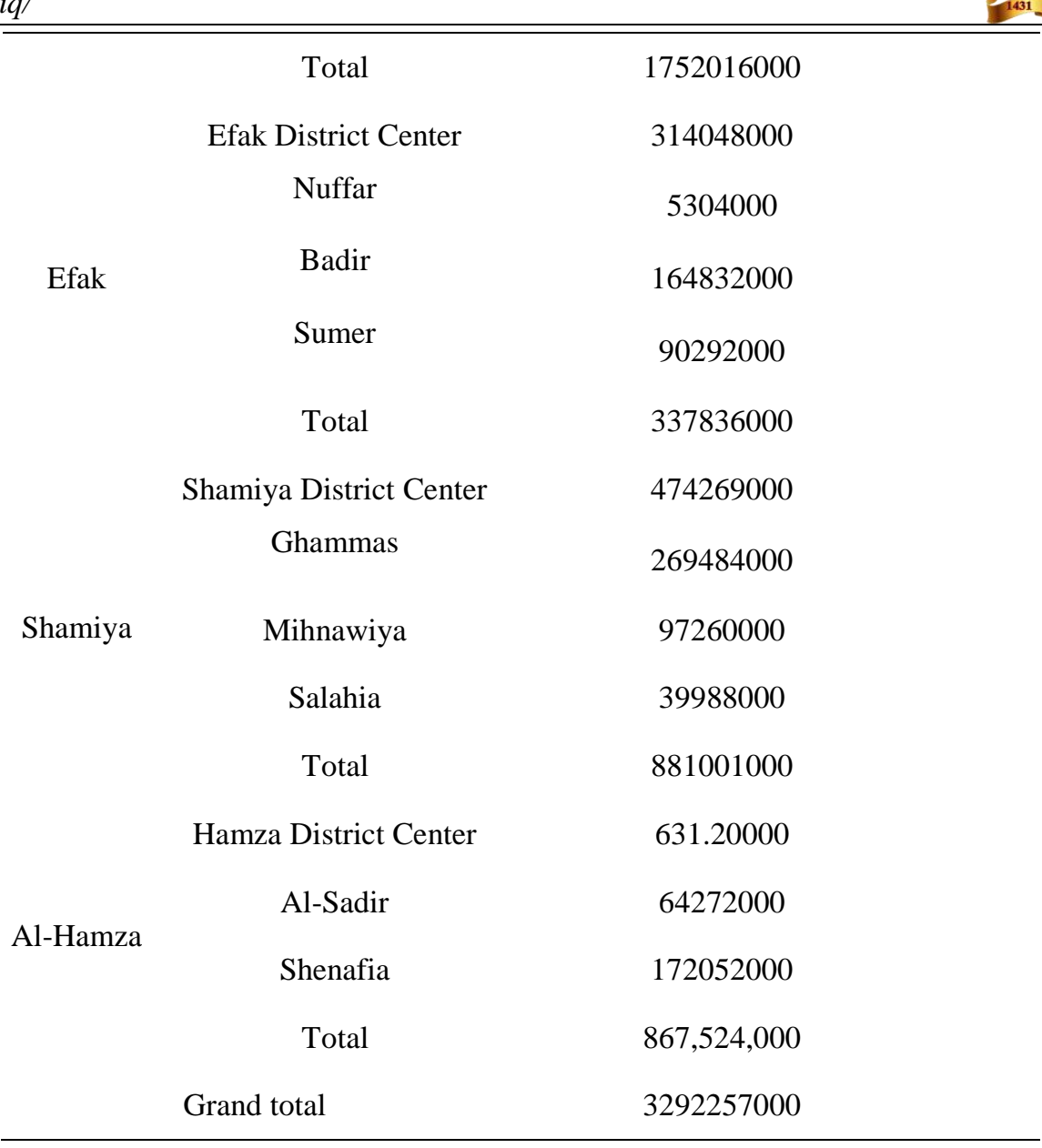

\section{- Solid Household Waste Components}

It is important to know the quantities and types of garbage, as well as its basic components and rate of generation, and all these important data must be known when developing a strategy for the disposal of this waste. It should be noted here that there are no waste collection and sorting points in the municipal institutions affiliated with Al-Diwaniyah Governorate, and therefore there are no percentages of household waste components in these institutions. Therefore, a study was based on a study prepared by the Qadisiyah Environment Directorate in cooperation with the office of the Governor / Follow-up Committee for the year 2010, as shown in the table no 5). A team from our directorate followed up and confirmed these results through field surveys.

TABLE 5. Shows the components of solid household waste.

\begin{tabular}{cc}
\hline Waste type & Percentage \% \\
\hline Organic materials & $50 \%$ \\
paper & $20 \%$ \\
minerals & $5 \%$ \\
glass & $10 \%$ \\
plastic & 15 th\% \\
\hline
\end{tabular}

\section{- Sanitary Landfill}

It is a pit whose depth and capacity depends on the nature and quantity of waste. After preparing the pit, it is isolated from the groundwater with an insulating layer of cement. The base of the pit is also equipped with a drainage network for water resulting from rainwater and the processes of decomposition of organic matter contained in some waste. A solid layer of gravel and sand is placed over it to facilitate the process of water entering the drainage network. The waste is distributed at the base of the pit and compacted, where the amount of compressed solid waste is from $0.8-1$ ton per m2. After the completion of the waste compaction process, its height after the compression process reaches 30-70 cm, and a layer of construction waste (ruble) is placed over it and tamped. On this layer of rubble, a second layer of waste is placed in the same way and so on until the site's height reaches $30-50 \mathrm{~m}$, and the site's height decreases within 20 years to about $30 \%$ of the original height. 
- The Sanitary Landfill Sites Must be Subject to Some Limitations, Which are as follows:

1. The transport side / Is the site served by a network that provides good access to it. Does the movement of transport, including it, cause congestion, for example, if it is located near narrow rural roads, or some notice on cars, or noise as a result of overcrowding of transport vehicles and machines?

2. Geological considerations / including the type of soil, the degree of its inclination, the porosity of the earth's layers, and the geographical nature of the area.

3. Hydrological considerations, including the proximity of the burial site to water reservoirs, such as artificial lakes, surface and ground layers, and rocky layers above groundwater.

4. The possibility of reusing the site, rebuilding and restoring it when it is filled with waste.

The sanitary landfill sites in Al-Diwaniyah Governorate are not working properly and in accordance with the environmental regulations and laws for land filling and do not conform to the conditions mentioned in the above points due to weak oversight over the vehicle drivers and landfill site officials in the province, and according to the field visits carried out by the work team, where it was found that there are Random heaping and burning of waste and not burying it properly. As this affects people in the present and the future in their daily lives through diseases that affect people in unhealthy atmospheres and polluted environments from all kinds of pollutants. These sites of landfill sites are unhealthy because they do not depend on organized work by the responsible authorities, nor monitoring nor follow-up committees. On the cases of diseases caused by the many pollutants caused by these sites.

There are seven sanitary landfill sites in Al-Diwaniyah governorate of different sizes, as shown in Table No. (6), and according to the data processed by the Diwaniyah Environment Directorate/Urban Environment Division/Service Activities Monitoring and Evaluation Unit.

TABLE 6. Sanitary landfill sites in Al-Diwaniyah Governorate.

\begin{tabular}{|c|c|c|c|c|c|}
\hline No. & Site name & Site address & $\begin{array}{c}\text { Year of } \\
\text { construction }\end{array}$ & Site area & $\begin{array}{c}\text { Does the site have environmental } \\
\text { approval }\end{array}$ \\
\hline 1 & $\begin{array}{c}\text { Sanitary landfill site in } \\
\text { Diwaniyah }\end{array}$ & $\begin{array}{l}\text { Diwaniyah - Samawah } \\
\text { Road }\end{array}$ & 1995 & $\begin{array}{c}52 \\
\text { dunum }\end{array}$ & yes \\
\hline 2 & $\begin{array}{c}\text { The site of the sanitary landfill in } \\
\text { Dagara }\end{array}$ & Hor Al Jabour area & 2010 & $1017 \mathrm{~m} 2$ & no \\
\hline 3 & $\begin{array}{c}\text { Sanitary landfill site in } \\
\text { Shanafiya }\end{array}$ & Al-Asra area & 2007 & 4 dunum & yes \\
\hline 4 & $\begin{array}{c}\text { The site of the sanitary landfill in } \\
\text { Shafi'i }\end{array}$ & Al-Dhaisi & 2008 & 3 dunum & no \\
\hline 5 & Sanitary landfill site in Saniyah & District 5 & 2014 & $\begin{array}{c}20 \\
\text { dunum }\end{array}$ & yes \\
\hline 6 & Sanitary landfill site in Hamza & Ramla area & 2012 & $\begin{array}{c}50 \\
\text { dunum }\end{array}$ & yes \\
\hline 7 & $\begin{array}{l}\text { The site of the sanitary landfill in } \\
\text { Al-Bdeir }\end{array}$ & District 4 & 2005 & $\begin{array}{c}10 \\
\text { dunum }\end{array}$ & yes \\
\hline
\end{tabular}

\section{CONCLUSIONS AND SUGGESTIONS}

1. There is no sorting of household waste and that the operations carried out by municipal institutions in the governorate are limited only to the processes of collection and transportation to get rid of this waste. Therefore, we suggest encouraging citizens to sort waste from the source by providing them with environmentally friendly plastic bags that are biodegradable in three colors depending on the type of waste As is the case worldwide.

2. The failure to benefit from waste (as an important natural resource with economic value) makes it a burden on the citizen and the state and has a bad environmental impact. Therefore, spreading and raising environmental awareness for all segments of society plays an important role about the danger of solid waste on the one hand and its economic value on the other hand.

3. The lack of an integrated database on this issue with the municipal institutions in the governorate. Therefore, we suggest adopting updated and accurate data for the quantity and type of waste presented, similar to this study, because it includes clear indicators for each administrative formation within the governorate, and thus provide investors with this data for the purpose of establishing a laboratory for collecting, sorting and recycling waste or converting it into useful raw materials.

4. The sanitary landfill sites in Al-Diwaniyah Governorate are irregular and do not conform to environmental 
determinants and are characterized by randomness. Therefore, light should be shed on these sites and their harmful environmental and health impact on the entire community of Al-Diwaniyah Governorate through studies procedures related to this subject and thus shed light on them by government agencies and increase Monitoring and follow-up in order to be subject to the environmental determinants of the landfill sites.

5. There are many legal obstacles facing investors in the field of recycling and marketing of products recycled from waste. Therefore, we suggest enacting laws regulating waste management law, especially to facilitate and encourage investment.

\section{REFRENCES}

[1] Data of the Diwaniyah Municipality Directorate, their books numbered 34888 and 34887 on December 29, 2016.

[2] Data of the Directorate of Diwaniyah Municipalities, their letter No. 19708 on 28/12/2016.

[3] Data of the Qadisiyah Statistics Directorate, their letter No. 1/3/1029 on December 28, 2016.

[4] Al-Qadisiyah Environment Directorate data, 1/1/3057 on 12/22/2016.

[5] Saadoun Al-Rabeawi, Hussein Reda, Development of a Solid Waste Management System (Applied Research in the City of Hilla), Journal of Economic and Administrative Sciences, 2016.

[6] Najm Al-Din Al-Ani, Hussein Abdul-Muttalib, Evaluation and Development of Municipal Solid Waste Management in the City of Najaf, Engineering Journal, 2005.

[7] The adequacy of Al-Yasiri, the site of the landfill in Al-Sayahieh and its impact on the neighboring areas, Journal of the College of Basic Education for Educational and Human Sciences / University of Babylon, 2015.

[8] Shaima Ratib Hassan, Al-Haytham Omar Selim, Environmental Pollution by Solid Waste "Garbage is a Gold Mine", Assiut University, 2008. 